\title{
A Critical Review of Vygotsky's Socio-Cultural Theory in Second Language Acquisition
}

\author{
Habibullah Pathan ${ }^{1}$, Rafique A. Memon ${ }^{1}$, Shumaila Memon ${ }^{2}$, Ali Raza Khoso ${ }^{3} \&$ Illahi Bux ${ }^{4}$ \\ ${ }^{1}$ Mehran University of Engineering \& Technology, Pakistan \\ ${ }^{2}$ Institute of English Language \& Literature, University of Sindh, Pakistan \\ ${ }^{3}$ Mehran University of Engineering \& Technology, Pakistan \\ ${ }^{4}$ Institute of English Language \& Literature, University of Sindh, Pakistan \\ Correspondence: Habibullah Pathan, Mehran University of Engineering \& Technology, Sindh, Pakistan.
}

\author{
Received: April 27, 2017 Accepted: April 8, 2018 Online Published: April 24, 2018 \\ doi:10.5539/ijel.v8n4p232 URL: https://doi.org/10.5539/ijel.v8n4p232
}

\begin{abstract}
The purpose of this study is to explore Vygotsky's contribution to the socio-cultural theory in the field of education in general, and applied linguistics in particular. The study aims to elaborate the impact of social-cultural theory in the existing body of literature. The study also reviews implications and applications of socio-cultural theory in second language acquisition (SLA). Moreover, this study also critiques the basic concepts of the theory and how far these concepts have been implicated in the domain of research. The central focus is to explore and to critically understand central ideas such as Zone of Proximal Development, mediation, scaffolding, internalization, and private speech. The socio-cultural theory focuses on what learners learn and the solution to their learning problems. Socio- cultural theory has made a great effect on learning and teaching languages. It also regards learning second language as a semiotic process where participation in socially mediated activities is very important (Ellis, 2000). Vygotsky (1987) singled out and studied the dynamic social surroundings which indicate the connection between teacher and the child. Moreover, he focused on the social, cultural and historical artifacts which play a pivotal role in the children's cognitive development as well as their potential performance. The study concludes with the idea of Williams \& Burden (1997) that socio-cultural theory suggests that education should be associated with learning to learn and making learning experiences meaningful and relevant to the learner. The study also suggests some pedagogical implications and offers teaching and learning practices in relation to socio-cultural theory.
\end{abstract}

\section{Introduction}

Vygotsky's important concepts of socio-cultural theory such as ZPD, mediation, scaffolding, internalization and private speech explored and highlighted suggest that their implication and application should be discussed. Through the analysis of applicability of socio cultural theory in SLL, it can be known how theory is applied in SLL classrooms. A number of studies conducted in the field suggest that to large extent, Vygotsky's ideas are applied in the discipline of education. The matter is their implication in L2 teaching. To what extent these ideas are implemented in the field of L2 teaching and learning. There are different approaches to learning and teaching English language. The application of socio-cultural theory in L2 classroom clearly lies in the task based approach. This approach suggests obvious implication of (SCT). It focuses the significance of social and collaborative modes of learning. Socio cultural theory came out of social and cultural interaction between people.

There are a number of language learning theories which are introduced by researchers in second language research. These theories are based on research and observation in the field of language learning. B. F Skinner's theory of behaviorism, Chomsky's theory of Universal Grammar, Krashen's five Hypotheses, connectionism and Vygotsky's socio-cultural theory have changed people' mind of language learning. This change was made possible through research and keen observation in the child's language learning development. Thus, the idea of Vygotsky is very important in second language learning because he introduced the concept of language learning in social interaction. His socio cultural theory basically lays emphasis on the role which is played by social, cultural and historical artifacts in the child's mental development. For example, by citing Lantolf \& Beckett 
(2009) actually named SCT as an educational paradigm to refer second language development. This statement is also verified with doctoral study done by Negueruela's (2003). It may be right to state that socio cultural theory is a theory of educational framework wherein the cognitive development of the child is promoted.

The present study tends to critically review Socio-Cultural Theory (SCT) in second language learning. This attempt is made to rationalize how the theory works in the language development of the child. The study also highlights main components of the theory such as Zone of Proximal Development, Mediation, Scaffolding, Internalization, and Private speech. As mentioned earlier that higher mental practices are developed through SCT. And social interaction is referred as a main process of learning component.

Moreover, research in SCT implicates the basic concepts of the theory and discusses that all cognitive development is symbolically mediated. Vygotskyan theory was extended to SLA by Lantolf (200) and Donato (2002). They described the way second language learners acquire language when they collaborate and interact with other people. The extended framework suggests collaboration and interaction as main ingredients of the theory. The basic components of socio cultural theory are mentioned and discussed.

\section{Zone of Proximal Development}

According to Vygotsky (1978), Zone of Proximal Development is for each child who is developing cognitively. The way he defined ZPD is the distance between the actual development level as determined by independent problem solving and the level of potential development as determined through problem solving under adult guidance or in collaboration with more capable peers (Vygotsky, 1978). This suggests that there is a big difference in the development of the child when he/she is in the company of more knowledgeable other. This difference shows that the child learns actively and promptly in the company of a mentor or a teacher. The idea of Vygotsky is to describe the development of the child when he/she works independently, but the difference is made when he/she is supported by the more knowledgeable other. The theory of Vygotsky testifies that the development of the child is possible in the guidance of a teacher, parent or any peer. Moreover, the idea of ZPD is interpreted by Mitchell and Myles (2004) as the domain of skills or knowledge wherein the child is not capable of independent functioning; however the child can get the targeted result when he is given relatively scaffolded. Another important concept in socio-cultural theory is mediation.

\subsection{Mediation, Scaffolding and Internalization}

According to Vygotsky (1978) Mediation is the representation of tools. Mediation is referred as the use of tools and these tools are adopted by the child to resolve a problem or achieve the target. So language is considered the most significant of the tools. The idea of mediation is treated in different words by Turuk (2008). For example, he describes mediation as the part in the development of the child which is played by more knowledgeable other in his life. Thus, language learning is deemed as a mediated process in SLA. In this regard, inter-subjectivity is key to the idea of mediation. However, Wertsch (1998) described inter-subjectivity as a shared understanding between the child and the adult. However, inter-subjectivity is very significant step in internalization. That is because the more significant person, mentor or teacher slowly reduces support and transfers responsibility to the learner. Mediation is the use of tools, a part played by other person in the cognitive development of the child.

Thus, the concept of scaffolding is very important in socio cultural theory. It is defined as the support which is given to the child to meet his cognitive potential. Citing Donato (2000) in this context is meaningful because he described scaffolding as a situation which is created by an expert, peer or parent wherein the child can take part and increase his/her current skills and knowledge to higher levels of performance. This means to facilitate the novice who can participate and improve language skills. A kind of help or support given to the leaner, in which he/she can easily participate and work under guidance of an expert. Such situation is generated by peer to facilitate the novice in language learning. Moreover, Schumm (2006) interpreted scaffolding that students are provided help in their language learning and such help is diminished or stopped because to make the child more independent. This is the way to produce independent learner and promote autonomy in language learning. Simultaneously, Verity (2005) looked at scaffolding as cognitive help given to the child that reduces his/her cognitive burden in the learning task. Moreover, Lantolf \& Beckett (2009) describe internalization as the process through which learners appropriate social tools of mediation, cultural artifacts, language and utilize it to regulate their cognitive activity. Vygotsky, (1978) defined internalization as

Any function in the child's cultural development appears twice, or on two planes. First it appears on the social plane, and then on the psychological plane. First it appears between people as an inter-psychological category, and then within the child as an intra-psychological category (p. 87).

The way Vygotsky (1978) described internalization is to understand the cognitive development of the child 
which is circled in two planes and these are social and psychological. In social plane, the child develops in the company of parent, mentor or teacher and then he or she becomes independent. Further, Lantolf \& Thorne (2006) stated internalization as the process of learning from social to individual. Similarly, Brown \& Ferrera (1985) treated Internalization in the same vein. First of all, the learner undergoes the process of problem solving activities in the company of others, however, he/ she tends to perform the tasks independently.

\subsection{Private Speech}

Private speech is often assumed to increase the child's early developing skills and it also enhances his/her task level of performance, achievement and success. To Vygotsky (1987), private speech is a child's social interaction and it becomes inner speech in the end. The study of Smith (2007) is known as rich in private speech in ESL classroom. The study indicates that private speech offers deep look into learners' mental process. Moreover, the study also provides access to teachers who reach learners' knowledge they already know. Lantolf \& Beckett (2009) argue that learners use private speech to manage and appropriate their cognitive behaviour. Thus, the basic to Vygotsky theory is the notion that children resort to private speech because it helps them overcome obstacles to task success and facilitates problem solving. However, this concept may be interpreted that to Vygotsky, early speech is global and multifunctional. Gradually, it separates into two functionally specific types. First, speech used to communicate with others, second, speech directed at communicating with the self.

\section{Critique of Socio-Cultural Theory (SCT)}

The application of the ZPD in practice is more problematic. Vygotsky failed to provide much about the effective use of ZPD in classrooms (Shayer, 2002). Piaget (1995, as cited in Matusov \& Hayes, 2000) suggests that in participation in the activity for which a child is not ready with a more knowledgeable other, leads mainly to imposing the partner' views and will not affect the structures of child's actions (i.e., social constraint). Mitchell \& Myles (2004) claim that most socio-cultural studies of language development within the ZPD have focused on individual lexical items or morpho syntactic features as found in traditional grammar. The concept of Zone of proximal development was critiqued by Lambert \& Clyde (2000) as follows:

We feel...that Vygotsky's ZPD presents a restricted view of learning processes and reduces the learner's role to one of passivity and dependence upon the adult (p. 29).

They actually failed to consider the application of ZPD in language learning. As researchers, Lambert \& Clyde (2000) felt restricted view of ZPD. They had rather provide findings to support their furnishing idea. Since Vygotsky (1997) argues that the role of teacher in the ZPD is to shape and fashion the social environment of the child and he/she cannot directly influence the child in the cognitive development. Vygotsky (1997) did not use the word scaffolding in socio cultural theory.

\subsection{Applications of SCT}

Socio cultural theory has influenced research in SLA. The applications and implications of the theory are strongly discussed in the social context of language learning. Moreover, Donato (2002) researched based on SCT and showed language learning as a social process. His study concluded that meaning is created through collaboration. The studies of Lantolf (2000) and Swain (2002) indicate the usefulness of peer interaction. It includes the way learners help each other during second language learning and simultaneously, the way they work together in form of focused activities. Verenikina (2008) concluded that in spite of some limitations of Vygotskyan socio-cultural theory and its basic concepts, researchers and practitioners have conducted a number of studies based on SCT. There is still deeper understanding required to operationalize scaffolding, ZPD in teaching practices. The notion of ZPD is used which engages interaction between expert and novice.

The theory presents the positive view of learner and provides meditational tools to promote him or her potential level. A main focus is placed on the active position of learner which is necessary to become a self-regulated learner. The main concepts of Vygotsky's SCT, ZPD, mediation, scaffolding, internalization and private speech have been reviewed and researched in the domain of SLA. A great deal of research has been conducted based on SCT in classroom. In this regard, citing Ellis (2000) who suggests that socio-cultural theory emphasizes how learners complete the task and indicate how interaction among learners can scaffold in second language acquisition. The theory focused on the social, cultural and historical artifacts which play a pivotal role in the children's cognitive development as well as their potential performance. Vygotsky revolutionized pedagogy with his thoughtful psychology of child development centered in the socio-cultural perspective.

\section{Conclusion}

The study concludes with the idea that it was really surprise for researchers with the idea that socio cultural factors are necessary for the cognitive development of the child in language learning. His genuine contribution to 
socio-cultural theory and his challenging ideas into this theoretical framework have a great place in the field of education, psychology and applied linguistics. Through the analysis of different findings and studies, it seems meaningful to state that Vygotsky singled out and studied the dynamic social surroundings which indicate the connection between teacher and the child. However, he focused on the social, cultural and historical artifacts which play a pivotal role in the children's cognitive development as well as their potential performance. Major concepts discussed aforementioned reveal the remarkable achievement of socio-cultural theory in learning and teaching processes. Most importantly, language use, the notion of ZPD, peer interaction and learning as a mediated process are Vygotsky's influential thoughts used and practiced in SLL, SLA. Broadly speaking, the application of these ideas is a matter of great significance. Nevertheless, this is the social-framework through which some insights can be sought and applied into practices of SLL. He lived intensively and proved his worth in the most varied psychological fields- psychological on general, developmental, and educational psychology, on the psychology of art etc. Interestingly enough, each of these fields felt the salutary influence of his innovative, bold and original ideas.

\section{References}

Brown, A. I., \& Ferrera, R. A. (1985). Diagnosing zones of proximal development. In J. Wertsch (Ed.), Culture communication and cognition: Vygotskian perspective (pp. 273-305). Cambridge: Cambridge University Press.

Donato, R. (2000). Socio-cultural contributions to understanding the foreign and second language classroom. In J. P. Lantolf (Ed.), Socio-cultural theory and second language learning (pp. 27-50). Oxford: Oxford University Press.

Ellis, R. (2000). Task-based research and language pedagogy. Language Teaching Research, 4(3), 193-220. https://doi.org/10.1177/136216880000400302

Lambert, B., \& Clyde, M. (2000). Re-Thinking Early Childhood theory and Practice. Australia: Social Science Press.

Lantolf, J. P. (2000). Introducing sociocultural theory. In J. P. Lantolf (Ed.), Sociocultural theory and second language learning (pp. 1-26). Oxford: Oxford University Press.

Lantolf, J. P., \& Beckett, T. G. (2009). Sociocultural theory and second language acquisition. Language Teaching, 42(04), 459-475. https://doi.org/10.1017/S0261444809990048

Lantolf, J. P., \& Thorne, S. L. (2006). Sociocultural theory and the genesis of second language development. Oxford: Oxford University Press.

Lantolf, J. P., \& Thorne, S. L. (2007). Sociocultural theory and second language learning. In B. Van Patten \& J. Williams (Eds.), Theories in second language acquisition (pp. 201-224). Mahwah, NJ: Lawrence Erlbaum.

Matusov, E., \& Hayes, R. (2000). Socio-cultural critique of Piaget and Vygotsky. New Ideas in Psychology, 18, 215-239. Oxford: Pergamon. https://doi.org/10.1016/S0732-118X(00)00009-X

Mitchell, R., \& Myles, F. (2004). Second language learning theories (2nd ed.). London: Arnold. Cambridge University Press.

Negueruela, E. (2003). A sociocultural approach to teaching and researching second language: Systemic-theoretical instruction and second language development (Ph.D. dissertation). The Pennsylvania State University.

Schumm, J. S. (Ed.). (2006). Reading assessment and instruction for all learners. New York: Guilford Press.

Shayer, M. (2002). Not just Piaget, not just Vygotsky, and certainly not Vygotsky as an alternative to Piaget. In M. Shayer (Ed.), Learning intelligence, cognitive acceleration across the curriculum from 5 to 15 years. UK: Open University Press.

Smith, H. J. (2007). The Social and Private Worlds of Speech: Speech for Inter- and Intramental Activity. The Modern Language Journal, 91(3), 341-356. https://doi.org/10.1111/j.1540-4781.2007.00584.x

Turuk, C. M. (2008). The relevance and implications of Vygotsky's socio-cultural theory in the second language classroom: ARECLS, 5, 244-262.

Verenikina, I. (2003). Understanding Scaffolding and the ZPD in Educational Research. Conference Papers of AARE/NZARE, Auckland.

Verenikina, I. (2008). Scaffolding and learning: its role in nurturing new learners. In P. Kell, W. Vialle, D. 
Konza, \& G. Vogl (Eds.), Learning and the learner: exploring learning for new times, University of Wollongong (p. 236).

Verity, D. (2005). Vygotskyan Concepts for teacher education. Pan-SIG Conference "Lifelong learning" proceedings. Retrieved from http://jalt.org/pansig/2005/HTML/Verity.htm

Vygotsky, L. S. (1978). Mind in society: The development of higher psychological Processes. Cambridge, MA: Harvard University Press.

Vygotsky, L. S. (1987). Thinking and speech. New York: Plenum Press.

Vygotsky, L. S. (1997). Educational Psychology. Florida: St. Lucie Press.

Wertsch, J. V. (1998). Mind as Action. Oxford: Oxford University Press.

Williams, M., \& Burden, R. (1997). Psychology for language teachers, a social constructivist approach. UK: Cambridge University Press.

Wood, D., Bruner, J., \& Ross, G. (1976). The Role of Tutoring in Problem Solving. Journal of Child Psychology and Psychiatry, 17, 89-100. https://doi.org/10.1111/j.1469-7610.1976.tb00381.x

\section{Copyrights}

Copyright for this article is retained by the author(s), with first publication rights granted to the journal.

This is an open-access article distributed under the terms and conditions of the Creative Commons Attribution license (http://creativecommons.org/licenses/by/4.0/). 